\title{
Özbekistan'da İslam, Siyasi Sistem ve Radikalizm
}

\author{
Efe ÇAMAN" \\ Kenan DAĞCI**
}

\begin{abstract}
Özet
Özbekistan'da İslami radikal akımların mevcudiyeti, hem özelde bu ülke için, hem de bölgesel güvenlik ve istikrar bakımından bir tehdit olarak görülmektedir. İslami dini akımların radikalleşmesi baskıcı otoriter rejimlerde meşru sistem içi meşruiyet kanallarının tıkalı olmasından kaynaklanmaktadır. Özbekistan vakası, bu hipotezi test edebilmemiz için iyi bir zemin sunmaktadır. Makale Sovyetler Birliği'nden günümüze Orta Asya Coğrafyası genelinde ve özellikle de Özbekistan özelinde İslam ve İslamcılık olgularına tarihsel-betimleyici bir yaklaşımla eğilmektedir. Özellikle siyasi ve militan İslamcılık ideolojisinin ve bu ideolojiye başvuran örgütlerin Özbekistan örneğinde nasıl bir geçmişe sahip olduklarını, hangi başat akımların üzerinde durulması gereken aktörler haline geldiklerini yanı sıra, siyasi hedeflerinin ne olduğu ve kullandıkları stratejileri de yazının ele aldığı diğer konulardır. Makalenin amacı, Özbekistan iç siyasetini anlamak hususunda kilit bir öneme sahip olan siyasi İslam konusunu Orta Asya araştırmaları ile ilgili akademik çevrenin dikkatine sunmak ve bu konudaki daha ayrıntılı bilimsel tartışmalar için başlangıç oluşturmaktır.
\end{abstract}

Anahtar kelimeler: Özbekistan, İslam, İslamc1lık

\begin{abstract}
The Islamic radical movements in Uzbekistan are considered as a threat to this country in particular and regional security and stability. The radicalization of Islamic movements stem from the fact that legitimate in-system channells for legitimacy are closed in oppressive authoritarian regimes. Uzbekistan case provides a basis for testing this hypothesis. This article deals with the phenomena, Islam and pan-Islamism, with a historical-descriptive approach starting from the Soviet Union to Central Asia in general and Uzbekistan in particular. What kind of history the political and militant Islamic ideology the organizations in Uzbekistan following this ideology have, which dominant movements have transformed into actors worth to mention, what are their political objectives and their strategy are the other issues discussed here. The aim of this article is to introduce the topic of political Islam which is of great importance for understanding the domestic policy of Uzbekistan to the academic community interested in research on Central Asia and to provide a starting point for further discussions.
\end{abstract}

Key words: Uzbekistan, Islam, Islamism

* Prof. Dr. Efe ÇAMAN, Türk Alman Üniversitesi Öğretim Üyesi; mefecaman@yahoo.com ** Prof. Dr. Kenan DAĞCI, Yalova Üniversitesi Öğretim Üyesi; kdagci@gmail.com 


\section{Sovyetler Birliği’nde İslam'a Yönelik Politikalar}

Marksizm'in temel ideolojik çerçeve olarak kabullenildiği Sovyetler Birliği'nde din politikalarının da Marksiyan bir yaklaşımla oluşturulduğunu ileri sürmek yanlış olmaz. Genel anlamda Marx'ın "halkın afyonu" olarak gördüğ ü din ve dine ilişkin toplumsal sistem, Bolşevik Devrimi sonrası eski toplumsal kimliklerle mücadelede kilit bir rol oynamıştır. Marx'ın dine yaklaşımını iki şekilde okumak mümkündür. Birincisi din olgusunun halkın bilinçlenmesine engel olan ve onun rasyonel hareket etmesinin önüne geçen olumsuz bir etken olduğu ve bu özelliği nedeniyle de tepeden tabana bir tür "bilinçlenme" olarak devrimci bir şekilde empoze edilen yeni Sovyet insanı (Homo Sovieticus) tipolojisine muhalefet potansiyelini içerisinde barındıran bir olumsuzluktur. İkincisi ise dinin halkın çektiği acılardan ve özellikle acımasız üretim ilişkilerinden sığınmak için bir liman, bir tür teselli bulma kurumu olarak görüldüğü daha yumuşak bir yorumdur. Gerçekten de Marx din için "... köşeye sıkıştırılmış yaratığın iç çekişi, kalpsiz bir dünyanın ruhu..." demekte ve bu bağlamda da acıları dindiren bir afyondan bahsetmektedir. (Marx\& Kritik, 1972,10) Her iki yorumda da din bir tür arkaik, ilkel ve modern zamanlarla bağdaşmayacak, dolayısıyla çağdaş dünyada kendisine duyulan ihtiyacın giderek azalarak sonunda da yok olacağı ön görülen kurum olarak algılanmaktadır. Tarihi modernist ve düz çizgisel (lineer) olarak okuyan Marksiyan ideoloji, modernleşmeye engel olarak gördüğü tüm geleneksel kurumlar gibi, dini de hâkim sınıfların lehine bir kurum olarak algılamakta ve bu nedenle de din karşıtı bir pozisyon almaktadır. Leninist Sovyet tipi devlet, devlet aygitını bu amaçla seferber eder. Bu durumda Sovyet ideolojisi dini ve dinsel kurumları reddettiği ve ideallerine engel olarak gördügü bir gelenek olarak dişlar ve reddeder.

Sovyet ideolojisine göre - ekonomik ilişkilerin sosyal tüm ilişki formları üzerinde belirleyici etkisi ya da diğer ifadeyle ekonomik determinizm ilkesi uyarınca - İslam "Arap tüccar kapitalizminin” bir aracı olarak görülürken, bir diğer mülahazada da "feodal sistemin zaferi" olarak algilanır (Nesemann,2001,212). Her halükarda Sovyet ideolojisine göre İslam siyasi ve ideolojik bir tehdittir ve bu tehdidin bertarafedilmesi ve ortadan kaldırılmasi lazımdır. Otoriter siyasi yönetim ve katı seküler yaklaşım gösteren Sovyet döneminin genel anlamda İslam politikasını özetleyen bir kavram kullanmak gerekirse, bu Tatari ve Shaykhutdinov'un da kavramsallaştırdıkları üzere, sekülerleştirme (secularization) olabilir (Tatari\& Haykhutdinov,2010,89).

Sovyetler Birliği'nde İslam konusuna yaklaşımda genellikle şöyle bir tasnif yapılabilir: 1- Başlangıç döneminde beraber yaşam olarak adlandırılabilecek bir dönem, 2- 1927'lerden itibaren başlayan saldırı dönemi, 3Kolektifleştirme ve korkutarak sindirme dönemi (1937-1938), 4- Bazı iyi- 
leştirmelerin yapıldığ 1 2. Dünya Savaş1 sonrası dönem ve 5- 1980'lerden itibaren İslam'ın dönüşü (Sartori,2010,317-318). Sovyetler Birliği'nde Ortodoks Hristiyanların ardından Müslümanlar dini aidiyetler sıralamasında ikinci büyük dini grubu oluşturmaktaydılar. Sovyetler Birliği'nin 1989 y1lında yapılan son nüfus sayımına göre ülkede 50 milyonu aşkın Müslüman yaşamaktaydı (Nesemann,2001,208). Nesemann Sovyet din politikalarında özel bir yer verir, çünkü İslam, başka hiçbir inanç topluluğunda olmad1ğ1 kadar yoğun şekilde sosyal düzeni normlandırmakta ve belirlemektedir (Nesemann,2001,208). Her ne kadar Lenin döneminde Orta Asya'da Müslümanlar Sovyetler Birliği’ndeki Ortodokslara göre görece daha özgür de olsalar, Sovyet din politikaları genelinde yaklaşılan İslam dinine yönelik uygulamalar özellikle hedefleri dikkate alındığında Rus Ortodoks Kilisesi'ne uygulanan yaklaşım stratejisinden çok da farklı olmamıştır. Birincil olarak Müslümanların aralarındaki ilişkileri belirleyen kurumsal çerçevesinin yok edilmesi hedeflenmiş, ikinci olarak ise dinsel bilincin propaganda ve hukuksal zemin çerçevesinde yürütülen bir ateizm politikası ile eritilmesine yönelik çalışılmıştır (Nesemann,2001,213). Özellikle devlet ve dinin birbirlerinden kesin sınırlarla ayrılması, bunun yanı sıra da okul ve kilisenin (dinin) birbirinden ayrılması, metot olarak kullanılmış (Nesemann,2001,213), böylelikle kamusal alanın tümden dinsel olan her şeyden izole edilmesi hedeflenmiştir. 1920'li yılların sonuna dek Orta Asya'da İslam şeriatının devam etmesi kısmi olarak tolere edilmiş, medeni hukuk, miras hukuku ve kısmi olarak ceza hukuku alanlarında faaliyet gösteren yerel mahkemeler varlıklarını devam ettirmişlerdir. 1923'ten başlayarak yerlileştirme (korenizatsiya) kampanyası çerçevesinde binlerce Müslüman hükümette sorumlu bürokratik pozisyonlara atandılar, fakat buna rağmen sayıca marjinal kaldılar (Sartori,2010,321). Hatta aynı dönemde Orta Asya'da Sovyet rejiminin kontrolünü arttırmak amacıyla "Şeriat Mahkemeleri Topluluğu” adıyla bir kurumsallaşmaya gidilmiş, İslam hukukunun "doğru yorumlanmasını" hedefleyen ve onu Sovyet devlet gözetimi altında Marksist-Leninist ideolojiye uygun hale getirmeyi amaçlayan bir yapı oluşturulmuştur; ancak bu topluluğun entegrasyon hedefinde başarılı olmadığı anlaşılınca topluluk lağvedilmiştir (Nesemann,2001, 213214). 1928 yılında ise bölgede yerleşik İslami vakıflar ortadan kaldırılmıştır ve mülkleri Sovyet merkezi hükümetine bağlı Halk Eğitim Komiserliği’ne devredilmiştir (Sartori,2010,320).

1927 ile 1931 arası dönemde Sovyet merkezi otoritesinin İslam dinine yönelik politikalarında ciddi bir dönüşüm meydana gelmiştir. Bölgede "hücum" olarak anılan bu yeni din politikasıly (McGlinchey,2006,128) merkezi Sovyet yönetimi Orta Asya'da kadınların özgürleştirilmesi hedefi altında ateizm politikalarının güçlü şekilde propaganda edilmesini sağlamış, İslami 
giyim-kuşama, özelde kadınların tesettürüne (geleneksel giyim geleneğine de) karşı bir saldırı başlatmışıır (Sartori,2010,321). Bu politika Sovyet yönetimince dolaysız biçimde "geri kalmış, ilerleme düşmanı İslam'a karşı" bir politika olarak görülmüştür ve bu bakımdan da 1917-1928 arası görece 1lımlı yaklaşımdan daha radikal ve İslam karşıtı bir yaklaşıma doğru sivrilen sert bir din politikası olarak yorumlanabilir. Orta Asya' da uygulanan bu çok daha sert din politikasına karşı tepkiler ortaya çıkmış, fakat bu tepkiler merkezi Sovyet otoritesinin gücünden dolayı kısa zamanda sona ermiştir. ${ }^{1} 1930$ 'larda bölgede bulunan İslami cemaatler zor kullanarak dağıtılmıştır (Hayit,1962, 169-172).

İkinci Dünya Savaşı ve sonrasında sert din politikaları yumuşamaya başladı ve devlet kontrolünde ibadet olanaklı hale geldi (MacLoad\&Mayhew,1997,21). 1940 'lı yıllarda giderek görece aşırı sert politikaların hafiflemesine paralel olarak, 1943 yılında Sovyet hükümeti Orta Asya Müslüman Ruhani Kurulu (Central Asian Muslim Spiritual Board - SADUM) adındaki kuruluşu hayata geçirdi. Her ne kadar SADUM merkezi hükümetten bağımsız ve biçimsel olarak otonom bir müftülük de olsa, aslında Moskova'ya bağımlı Orta Asya yönetim aparatının bir parçasıydı (Eric\&McGlinchey,2006,129). Merkezi Özbekistan'da bulunan SADUM, genel olarak Özbekler tarafından benimsendi. SADUM örneğinde olduğu gibi, Moskova bölgede İslam'1 kontrol etmeyi temel bir strateji olarak görmüş, dönemsel algılarına göre kimi zaman yumuşak, kimi zaman ise sert politikalar vasıtasıyla bu amaca yönelik hareket etmiştir. Bu yaklaşımın en somut örneklerinden biri Orta Asya ve özelde de Özbekistan'da eğitim alanında meydana görülmektedir. Eğitim alanının İslam'ın ve İslami akımların devamlılıklarındaki önemi açıktır. Bu bağlamda merkezi hükümet bir taraftan İslami elitleri kontrol etmeye çalışmış ve bunu SADUM gibi kurumsal önlemlerle başarmış, diğer taraftan eğitim sistemini kendi kontrolünde tutmaya gayret etmiştir. Böylelikle genel olarak Orta Asya bölgesinde ve özelde de Özbekistan'da Sovyet döneminde İslami ya da İslam'1 referans alan eğitim sistemi bütünüyle tasfiye edilmiştir ve bu yolla İslam'ın kamusal alandan uzaklaştırılması sağlanmıştır. Bu politikanın bir sonucu olarak Sovyet sonrası dönemin başlangıcı olan 1990'lı yılların başında Özbekistan da dâhil olmak üzere tüm Orta Asya Sovyet ardılı bölgelerde halk bazında İslam ritüelleri ve İslam öğretisi hakkında genel bilgiler son derece eksikti.

Pelkman Sovyetler Birliği'nde dinin “objektifleştirilmesi”ya da “objeleştirilmesi" kavramını kullanarak (Objektivierung der Religion), bu dönemde

1 Ayrıntılar için bkz. BaymirzaHayit, SovietrussischeOrientpolitik am BeispielTurkestans, (Köln, Berlin, 1962), 
din politikalarının nasıl bir strateji takip ettiğini açıklamaya çalışır. Buna göre din hayatın bölünmüş bir alanı olarak kavranır ve dini aidiyet de kültürel mirasla ilgili bir bağlam olarak görülür. Böylelikle Sovyet rejimi dini aidiyetle etnik ve ulusal kategoriler arasında istemeden de olsa bir bağlantı kurmuş olur (Pelkmans,2006). Rejimin geç dönemlerinde örneğin bir Kazak, Komünist Partisi'nin üyesi olarak ateist bir dünya görüşüne de sahip olsa, Müslüman olduğunu iddia edebilirdi, çünkü Müslümanlık kültürel geçmişini ifade etmekteydi (Pelkmans,2006). Dinsel olanın kimlik yapıcı ya da güçlendirici folklorik bir öğeye indirgenmesi olarak yorumlanan bu durum, özellikle hâlihazırda mevcut Sovyet ardılı Orta Asya rejimlerinde din ve kimlik ilişkilerini anlamak açısından önemli olsa gerektir. Pelkmans'a göre böylesi bir perspektiften bakıldığında ateist bir Müslüman tezat oluşturmamaktaydı.

Sovyetler Birliği'nin bu yaklaşımının reel politik ile açıklanması rasyonel olabilir. Dinin pratik uygulamaları ile değil, salt kimliksel-tarihi bir öğe olarak algılanması ve bu alg1 çerçevesinde kabul görmesi, radikal-laik bir din-toplum ayrıştırması üzerine inşa edilen sistemde dine tamamıyla ve kategorik olarak karşıt bir pozisyona göre daha fazla başarı şansına sahipti. Tamamen ortadan kaldırmaktansa istediği yönde dönüştürmek, daha az toplumsal muhalefetle karşılaşacaktı. Tamamen folklorik bir öğe haline indirgenen din, geçmişle, yani tarihsel olanla, olup bitmiş olanla alakalıydı, dolayısıyla tarihsel olduğu müddetçe meşruydu. Tarihsel olanın yerini alan homo sovieticus yani Sovyet insanı için dinin işlevsel ve yeniden "canlı" bir duruma büründürülmesi ise modern olandan sapma ve gerilik-gericilik olarak siniflandırıliyordu. Her ne kadar Hallbach İslami bir yeniden doğuş iddiasının Sovyet ardılı coğrafya için kullanılmaması gerektiğini, çünkü Sovyetler Birliği'nde İslam'ın hiçbir zaman kaybolmadığını ileri sürse de (Halbach,2002,25), bu bağlamda kaybolmayanın dini pratikler bütünü ve toplumsal rolü bağlamında bir İslam olmadığ1, olsa olsa Pelkman'ın kullandığı manada “folklorik" bir İslam olduğu unutulmamalıdır. Zaten Hallbach'ın kendisi de sözünü ettiği İslam'ın "gündelik İslam" veya “gelenek İslam'1" olduğunu kabul etmektedir (Halbach,2002,25). Gene de Freitag-Wirminghaus'un da işaret ettiği üzere, İslam ahlaki temeller ve gündelik ritüeller seviyesinde bile olsa, Sovyet döneminde var olan sisteme paralel olarak tüm olumsuzluklara rağmen sürekliliğini sürdürmeyi başarmış ve kimlik belirleyici en önemli sosyal öğe olmayı da sürdürmüştür Freitag\& Wirminghaus, 2005,681-695). Her ne kadar bu manada bir İslami yeniden doğuş ileri sürülemese de, Hallbach da dâhilbirçok yazar teolojik, hukuki ve felsefi bağlamlarda İslam dininin bölgede bir "yeniden doğuşundan" söz edilebileceğini teslim etmektedir (Halbach,2002, 26).

Sovyet geçmişe ilişkin olarak ifade edilebilecek en kesin veri, İslam'ın ve İslami geleneklerin Sovyet geçmişinde yaşanan tüm baskılara rağmen 
Özbekistan' da varlığını sürdürmeyi başardığı, İslami geleneğin kesintiye uğramadan günümüze dek sürekliliğini koruduğu, hayat biçimi ve de kimliksel manada özdeşleşme bakımından İslam'ın en önemli belirleyici olma özelliğinin sürdüğ̈̈dür (Olimaya\&Tolipoy,2011,3).

\section{2. Özbekistan Yönetimin İslam'a Yaklaşımı ve Din Politikaları}

Özbekistan'da siyasi anlamda iki tür İslam'dan söz etmek mümkündür. Bunlardan birincisi Özbek resmi devlet politikalarında da karşımıza çıktığı üzere, devlet destekli ve devlet tarafindan kontrol edilen bir "resmi İslam", diğer taraftan ise Özbek hükümetine karşı pozisyon almış bulunan "devlet dış1 İslam" olarak tanımlanabilir (Hanks,2007, 209-221,210). 1991 yılında bağımsızlığını elde ettiğinden bu yana genel olarak insan hakları, özelde ise konumuzla ilintili olduğu üzere din özgürlüğü konusunda sıklıkla eleştirilmektedir. Eleştiriler özellikle Özbek yönetiminin din özgürlüğünü kısıtlay1c1 yönetsel önlemler almasına yöneliktir. Özbek yönetimi İslam ve güvenlik konusunu ortak bir potada ele almakta ve bir taraftan devlet tarafindan kabul gören, desteklenen ve kontrol edilen bir resmi İslam'1 desteklemekte, diğer taraftan ise bu devlet İslam'ı dışındaki akımlara güvenlik penceresinden bakmakta ve bu algıya yönelik politikalar üretmektedir. Bu algıda Özbekistan hükümetine karşı harekete geçmiş olan muhtelif İslami hareketlerin etkisi bulunmaktadir.

Özbekistan'da yukarıda ele alınan Sovyet tipi din politikalarının bir versiyonu uygulanmaktadır. Bu politikaya göre devletin temel çıkarı din işlerinin devlet tarafindan düzenlenmesidir. Bu politikanın merkezinde yatan temel mantığa göre, din sadece inançlarla, değerlerle ve dini pratiklerle ilintili olan ve bunların - kamusal alanda - ifadesine ilişkin bir şey değildir; bilakis bir tür sosyal kontrol aracıdır ve anayasal düzen ile ve devlet tarafindan düzenlenmesi gereken bir şey ile bağlantılı olarak algılanır (Gunn,2003,402-403). Gunn'a göre Sovyet modeli bu din politikaları yaklaşımında temelde üç öğe bulunmaktadır. 1- Dini kontrol etmek amaçlı tasarlanmış olan yasalar ve kurumlar, 2- Bir tür resmi İslam tasarlamak ve bunu desteklemek, 3- İslamcı rejim karşıtlarını sindirmek (bu resmi İslam'dan sapan ve devlet otoritesine meydan okuyan tüm gruplar bu kategoride yer alır) (Gunn,2003,403). Sovyet ardılı tüm cumhuriyetlerde bu yaklaşıma paralel bir din politikası takip edilmektedir. Özbekistan da bu bağlamda bir istisna oluşturmamaktadır.

Özbekistan anayasası din özgürlüğü ve vicdan hürriyetini garanti etmektedir (Özbekistan Anayasası, md 18). Anayasa metnine göre Özbekistan din ve devlet işlerinin ayrıldığ 1 seküler bir devlettir (Özbekistan Anayasası, md. 61). Özbekistan anayasal olarak dini temelli her türlü düşmanlığı yasaklamaktadır 
(Özbekistan Anayasası, md. 13) ve inançsızlığı da koruması altına almaktadır (Özbekistan Anayasası, md.31). Aynı zamanda seküler devletin gereği olarak dini temellerde bir parti kuruluşu da Özbek Anayasası tarafından yasaklanmıştır (Özbekistan Anayasası, md.57).

Özbekistan din işlerini Sovyet sisteminde olduğu gibi Merkezi Müftülük üzerinden yürütmektedir. Sovyet döneminde devlet ve Müslümanlar arasında birincil iletişim kanalı olan müftülükler, devletin din işleri üzerindeki başat ve belirleyici konumunu kurumsal olarak tesis etmekte, devletin tercih ettiği bir din eğitimini yine devletin tercih ettiği genel yaklaşıma uygun olarak sağlamaktaydı. Bu Sovyet mirası diğer Orta Asya devletlerinde olduğu gibi, bağımsızlık sonrasında Özbekistan'da da benimsendi. Devlet müftülük kanalıyla camilerin işlevine devam etmesini sağlamakta, aynı zamanda medreselerde din eğitimini desteklemektedir /Gunn, 2003,406). Esasen devlet ve müftülük arasındaki ilişki yazılı hukuk tarafından belirlenmemiştir, hatta hukuki mevzuata göre müftülügün devlet tarafindan kontrolü reddedilmektedir. Ancak uygulamada ise müftüler merkezi hükümet tarafindan kontrol edilmektedir (Gunn,2003, 406). Hükümet müftülere Cuma hutbeleri konusunda direktif verebilmekte, hatta seçimlerde hangi adaya oy verilmesi gerektiğ $i$ gibi konular da bu vaazların konusu olabilmektedir. Merkezi otoritenin hoşuna gitmeyen müftüler görevden alınabilmektedir. Özbekistan'da devlet tarafindan kabul görmeyen imamların camilerde görev yapmaları olanaklı değildir. Literatürde "paralel İslam" denilen devletten görece bağımsız İslami grupların açıkça kendi cemaatlerini oluşturmaları engellenmektedir. Bu tür girişimlerde bulunan dini kişilikler hapis cezasına çarptırılabilmektedirler (Gunn, 2003,406). Gunn devletin resmi İslam'1 kontrol etmesi ile halkın bu resmi versiyona güveni arasında korelasyon kurmakta, kontrol arttıkça güvenin azaldığını ileri sürmektedir. İslam üzerinde devlet eliyle kontrol mekanizması kurulması gerekliliği bizzat Özbekistan lideri Kerimov'un İslamcılığ 1 ya İslam'ın siyasileştirilmesi, ya da siyasetin İslamileştirilmesi olarak kavranması konseptine göre şekillenmektedir. Buna göre, "ithal edilen" İslam, Özbekistan'da suni bir alan oluşturmakta, amacı İslam'ı siyasete alet etmek, veya siyasi alanı İslami öğelere göre şekillendirmek stratejisini gütmektedir (Gaziev,2000,2). Bu durumda, var olan düzeni sona erdirmeyi otomatikman talep eden bir siyasi İslamcilık mevcuttur ve Kerimov'a göre bu duruma seyirci kalınmamalıdır.

1991'den bu yana kesintisiz olarak Özbekistan'da iktidarda olan 1938 doğumlu Cumhurbaşkanı İslam Kerimov Sovyet döneminde Özbekistan Birlik Cumhuriyeti Devlet Planlama ve Finans Dairesi'nde kariyerine devam ederken 1989 y1lında Özbek Komünist Partisi'nin Genel Sekreteri olmuş, 1990'da Özbekistan Üst Sovyet'i Başkanlığa seçmiş, aynı zamanda Merkezi 
Sovyet Politbüro üyesi olmuştur. Geçmiş kariyeri halk tabanında kendisini 1991 sonrasında artan oranda Müslüman kimliği ile ortaya koymaya çalışan Kerimov'un "Müslüman kimliğine" yönelik şüphe oluşmasına neden olmaktadır. Hanks'ın vurguladığı üzere, stratejik olarak şahsı hakkında dinle ilişkileri sorunsuz bir lider imajı oluşturmaya çalışan Kerimov, gerçekten de 1991 'den bu yana konuşma metinlerinde sıklıkla Kuran'danalıntılarda bulunmakta, biçimsel İslami öğelere önem atfetmekte ve bunu kamuoyu ile paylaşmakta, dahası Hacca gitmek gibi mütedeyyin halkın hoşuna gidecek İslami vurgulara gönderme yapmaktadır. Kerimov'un bu yaklaşımı, giderek dindarlaşan Özbekistan'daki kamuoyu beklentileriyle örtüştüğü oranda doğru bir siyaset olarak yorumlanmalıdır. Literatürde devlet destekli resmi İslam çerçevesinde cami sayısı artmakta, Arapça ve İslami ilimler konusunda eğitim alan öğrenci sayısında da artıştan söz edilmektedir (Hanks,2007,215-216). 1991'den bu yana ulus kimliği inşa etmeye çabalayan Özbekistan hükümeti, Sovyetler Birliği döneminde yapay olarak oluşturulmuş olan Özbek kimliği ve bu kimlik etrafında vücut bulmuş Özbek devletinin kimliğini devlet eliyle desteklemeye ve yerleştirmeye çabalamaktadır. Dinsel kimlik, adı her ne kadar açıkça telaffuz edilmese de, bu bağlamda öne çıkmaktadır. Kerimov'un bilinçli olarak adını koymadan, sadece "maneviyat" olarak dillendirdiği İslam, devlet eliyle yukarıda da altı çizildiği üzere "resmi İslam" şeklinde öne çıkarılmaktadır. Ancak devlet kontrolü dışında din eğitimi verilmesi, devletin din görevlileri haricinde İslami kı1ık kıyafetle kamusal alana çıkılması vb. birçok konuda devletin katı kısıtlamaları, din özgürlüğü skalasında Özbekistan'ın hâlihazırda ciddi antidemokratik uygulamaları olduğunu ortaya koymaktadır. Aynı zamanda bu devlet kontrolü, devlet dışı dini akımların radikalleşmelerine ve kendilerini hukuk dışı yollardan ifade etmelerine neden olabilmektedir. Orta Asya devletlerinin diğerlerinde de görüldüğü üzere, devlet aygıtı istihbari faaliyetlerini din alanında yoğunlaştırmaktadır. İslam'ın siyasallaşması konusuna odaklanan bu yaklaşım biçimi, terörizm ile savaşı gerekçe olarak kullanarak dini alanı kontrol etmeye çalışmakta, İslamcı aktivistleri baskıcı yöntemlerle takibata almakta, bunun sonucu olarak da daha fazla İslamc1 radikalizme neden olmaktadır (Seifert,2012, 15). Dahası, bu yöntem seküler bir demokratik temel düzeni kabul edebilecek mülayim ve 1lımlı İslami hareketleri de radikalleştirmekte, böylece aslında kendilerince takip edilmekte olan çıkarlara da hizmet etmemektedir.

\section{Radikal İslamcı Akımlar ve Siyasi Hedefleri}

Günümüzde İslamcı akımlargenelde Orta Asya'da, özelde ise Özbekistan'da mevcut yönetimlerin meşruiyetlerinin İslami söylemlerden hareketle altını oymak taktiğini uygulamaktadırlar ki bu yaklaşım Ortadoğu menşeli bir siyasi 
stratejidir. Ortadoğu örneğinde görüldüğü üzere, İslam'in siyaseten araçsallaştırılması ve özellikle mevcut rejimlere karşı militan İslamcı grupların ideolojilerine meşruiyet kazandırıcı zemin oluşturması (Baran,2004,1-9), Orta Asya'da da karşılaşılan bir durumdur. Özbekistan'da devlet kontrolü dışındaki tüm İslamcı akımlar, potansiyel tehdit olarak algılanmaktadır. Orta Asya'da tipik bir biçimde karşımıza çıktığı üzere, Özbekistan'da da İslamcı akımlar Selefi akımlara tasnif edilen ve bulundukları coğrafyanın ve kültür havzasının geleneksel İslami köklerinden bağımsız gelişen akımlardır. Orta Asya genelinde ve Özbekistan özelinde 1lımlı Hanefi-Sünni İslam anlayışı hâkimdir ve bu anlayış yüzyıllardır bu coğrafyanın dini yaşantısını ve dünya görüşünü şekillendirmektedir. Ne var ki bölgede ortaya çıkan radikal militan İslamcı hareketler, Vahabi-Suudi orijinli Hanbelî-Sünni akımlar şeklinde tezahür etmektedir (Cornell,2005, 626). Vahabi İslam anlayışı özellikle Fergana Vadisi'nde oldukça yaygıdır. Bu bölgenin sosyo-ekonomik yapısı yanında, Tacikistan ve Afganistan'da aktif konumda olan örgütsellik bağlantılarının Özbekistan sınırları içerisinde bu bölgede yoğunlaşması ve burayı merkez alarak ülke sathında aktif hale gelmesi, dikkatleri Fergana Vadisi'ne çekmektedir. Vahabi etki alanı da daha çok bu bölgede göze çarpmaktadır. Suudi Arabistan menşeli finansal destekle beraber burada mevcut kitle - çoğunlukla öğrenciler - radikal İslami akımların etki alanına girmektedir. Ülkede meşru muhalefetin imkânlarının sınırlı olması, militan akımların işini kolaylaştırmaktadır. Özbekistan'da Özbekistan İslami Hareketi (ÖİH) ve Hizb-ut Tahrir (HT) karşımıza çıkan iki önemli İslamcı harekettir.

\section{4. Özbekistan İslami Hareketi}

Özbekistan İslami Hareketi adındaki örgüt, çeşitli İslami fraksiyonların oluşturdukları bir tür koalisyondur ve Özbekistan'daki Kerimov rejimine karşı muhalefet etmektedir. Kökleri 1990'lı yılların başlarına dek uzanan ÖİH, Tahir Yoldaşev ve Cuma Namangani tarafindan Kerimov yönetimine karş1 cihat ilan ederek faaliyete geçti. Tahir Yoldaşev Özbekistan'da Sovyetler Birliği'nin dağılması ve Özbekistan Cumhuriyetinin 1991 yılında bağımsızlığını elde etmesinin ardından, 1990'lı yılların başında ortaya çıkan sayısız siyasi hareketten biti olan Adalet Partisi'nin (AP) lideriydi. AP İslami hukuk sisteminin Özbekistan'da uygulanmasını talep eden programıla İslamcı siyaseti Özbekistan'da gündeme getiren ilk parti oldu. 1992 y1lında Namangan'da bulunan Otavalihon Camii çevresinde yapılanan örgüt, dört radikal İslamcı grup olan Adalet, İslam Laskarlari, Barak ve Tauba fraksiyonlarını ÖİH altında birleştirdi (Baran\&Starr\& Cornell, 2006,25-26). Özbekistan'daki birçok İslamcı grubu çatısı altında toplamayı başaran Yoldaşev yönetimindeki AP, Kerimov yönetiminin tepkisini çekti. Her ne kadar Kerimov yönetimi bu dö- 
nemde çeşitli İslami öğeleri kısmen de olsa Özbekistan siyasi sistemine entegre etmeyi içeren bir siyasi yaklaşım içerisinde de olsa, İslam Kerimov'un devlet tarafından tanımlanan çerçevenin dışındaki İslami/İslamcı hareketlere karşı tutumu Sovyet döneminden miras alınan yaklaşıma yakın sertlikte olmaktaydı. 1992-1993 yıllarında Kerimov yönetimi İslamcı örgütlere karşı harekete geçince, gelecekte İslamcı ÖIH'e katılacak olan 2000'e yakın aktivist Afganistan'a ve Tacikistan'a kaçmak zorunda kaldı (Lisnyanski,2008,16). Bunların çoğu Birleşik Tacik Muhalefeti saflarında Tacikistan'daki iç savaşa katıldı. Bu bağlamda AP yasaklandı, partinin birçok ileri gelen yöneticisi tutuklandı. Ne var ki başta Tahir Yoldaşev olmak üzere partinin bazı ileri gelenleri kaçmayı başardılar. Partinin diğer lideri Cuma Namangani Sovyetler Birliği'nin Afganistan Savaşı'nda yer alan bir askerdi. Savaş sonrasında Tacikistan İslami Direniş Örgütü'nün liderlerinden olan Muhammet Şarif tarafından desteklenen İslamcı Toyba Hareketi ile bağlantıya geçti, ardından Afganistan'da bulunan Tacik direnişi tarafindan eğitildi (Mann,2002,295). Dada sonraları Cemaat-el İslami adlı İslamcı örgütün eğitimini alan Namangani, Suudi istihbaratı ile temasa geçerek, bu kanal üzerinden İslamcı teröristlerin yetiştirildiği “Miram Şah” kampına gönderildi. 1993'te Tacikistan'a geri dönen Namangani, İslamcı örgütler arasında Pakistan istihbaratı tarafından desteklenen bir network oluşturdu, 1996 yılında Suudi Arabistan'a gitti, 1998 yılında ise Tahir Yoldaşev ve diğer lider kadro ile bir araya gelerek ÖİH'i kurdu (Mann,2002,296). Namangani ÖİH askeri kanadının liderliğine yükseldi (Baran\&Starr\&Cornell,2006,26).

ÖİH'in temel amacı, var olan siyasi düzeni değiştirerek İslami bir rejim inşa etmektir. Hizb-ut Tahrir gibi ÖİH de Fergana Vadisi'nde bir İslam devleti kurmayı hedeflemektedir (Lisnyanski,2008,17). ÖİH 1999 yılında Özbekistan'ın başkenti Taşkent'te gerçekleştirdiği saldırı sonrasında dikkatleri üzerinde toplamıştır. Örgüt bu dönemde özellikle Kırgızistan'ın güneyinde bulunan Batken bölgesinde faaliyet göstermekte ve örgütlenmekteydi. 2000 yılında ABD hükümeti ÖIH'yi en tehlikeli terörist örgütler listesine dâhil etti (Lisnyanski,2008,16) ve 2001 yılında yaptı̆̆ 1 bir konuşmada dönemin ABD başkanı Bush ÖİH'yi Usame Bin Ladin ile bağlantılı bir örgüt ve bu bağlamda da ABD tarafindan El-Kaide ile hedef olan örgütlerden biri olarak niteledi (Mann,2002,294-304). Özbek istihbaratı da Tahir Yoldaşev'in Usame Bin Ladin ile bağlantısı olduğuna inanmaktaydı Lisnyanski,2008,17). ABD tarafından yürütülen "Terörizme Karşı Savaş"2 stratejisi çerçevesinde Afganistan'da ve çevre bölgelerde yürütülen operasyonlarda ÖİH ağır kayıplar verdi. Mezar-1 Şerif bölgesinde 2001 yılında ABD tarafından yürütülen operasyonlarda ÖİH

2 War against terrorism.

NİSAN 2014 - EKİM 2014 
lideri Cuma Namangani'nin ölü olarak ele geçirilmesi ÖİH'in uğradığı kayıplara örnek teşkil edebilir. ${ }^{3}$ Namangani, örgütün askeri lideri ve Taşkent saldırılarının planlayıcısı olarak Özbekistan'da da ölüm cezasına çarptırılmıştı. Özbekistan yönetimi, ABD'nin 11 Eylül saldırıları sonrasında bölgedeki İslamcı hareketlere yönelik değişen algısından yararlanmasını ve kendi özel durumunu ABD hükümetlerine ve dünya kamuoyuna radikalizm ve İslamcı terörizm ile savaş görünümünde lanse etmeyi bildi. Bu bağlamda Batılı ülkeler de Özbekistan'ın ÖİH'e karş1 takındığ 1 sert tutumu büyük oranda görmezden gelen eden bir tutum sergilediler. 2005 sonrası ÖİH Veziristan'da güçlenen El Kaide ile bağlarını sıkılaştırmaya başladı. El Kaide ile bağlantılı olan bu ÖİH militanları örgütün askeri kanadını temsil etmekte ve kendilerine İslami Cihat Grubu (íCH) demektedirler Lisnyanski,2008,17).

\section{Hizb-ut Tahrir}

Hizb-ut Tahrir (HT) 1990'ların sonlarına doğru Özbekistan'da faaliyete geçen bir örgüttür. Kökleri 1953 yılında tanınmış Kudüslü İslami düşünür ve hukukçu Takuiddin an-Nabhani'ye uzanan bu örgütün Özbekistan'a girişinin Ürdünlü vaizlerin 1990'larda Özbekistan'a gelmeleriyle gerçekleştiği düşünülmektedir (Karagiannis,2006,264). Örgütün Özbekistan'daki ayağının diğer adı İslami Özgürlük Partisi'dir. ${ }^{4}$ Al-Nabhani tarafından formüle edilen temel hedef, Osmanlı İmparatorluğu'nun yıkılması ardından kaldırılan Halifeliğin yeniden kurulmasıdır. 1977 yılında Al Nabhani’nin ölümünün ardından, Filistinli din adamı Yusuf Abdul Kadim Zallum örgütün yönetimini almıştır ve 2003 y1lındaki ölümüne dek liderliğini sürdürmüştür. Zallum'un ölümünden sonra ise örgütün başına Abu Yasin takma adını kullanan Ata İbnu Halil Abu Raşta geçmiştir (Baran\&Starr\& Cornell,2006,19). Abu Raşta sonrasında HT daha saldırgan bir strateji takip etmeye başlamış, aynı zamanda Ortadoğu ve Osta Asya'da yayılarak 40'tan fazla ülkede faal duruma geçmiştir. İdeolojik merkezi Londra olan HT'in resmi merkezi ise Ürdün'dür (Baran\&Starr\&Cornell, 2006,19).

HT, ideolojik olarak Batı tipi demokrasi ve liberal piyasa ekonomisinin ideolojik eleştirisini yapan bir örgüttür. Antisemitist ve Batı karşııı bir ideoloji benimseyen HT, Batı tipi "özgürlük" konseptine de karşı çıkmaktadır. HT merkezli "küresel Halifelik" olarak özetlenebilecek siyasi İslamcı hedef günümüzde birçok cihatçı radikal örgüt tarafından nihai amaç olarak görülmektedir. HT Selefi akımlara yakın bir örgüttür. Sosyal adalet anlayışı, yaşam

3 Ayrıntılı Bilgi için Bakınız. http://www.theguardian.com/world/2001/nov/26/afghanistan. iantraynor.

4 The Islamic Party of Liberation. 
tarzı ve dünya görüşü, Hanefi İslam'ın çerçevesinde yer alan Sufi anlayışı benimseyen İslami akımlara, Kadirilik ve Nakşibendîlik gibi köklü ve mülayim çizgideki İslami cemaatlere ve yapılara da karşı pozisyon almaktadır (Seifert\&Arne,2010,6). HT buna rağmen şiddeti biçimsel metot olarak reddeden bir strateji benimsemiş görünmekte ve bu nedenle de birçok Batılı ülkede serbestçe faaliyetlerine devam edebilmektedir. Avrupa'da sadece Almanya HT'i yasaklamıştır (Baran\&Starr\&Cornell,2006,20). Baran ve diğerleri, HT'in Bolşevik tipi metodolojiyi ve Marksist terminolojiyi harekete adapte ettiğini ve tepkisel bir radikal ideoloji oluşturmadaki başarılarına dikkat çekmektedir. Gerçek halifelik, adil tolum vb. sloganlar Marksist ideolojiden ödünç alınan kavramlarla desteklenmektedir. Son ana kadar şiddetin reddedilmesi, ancak son etapta bu yola başvurulabilecek olması gibi başka benzerliklere de dikkat çekilmektedir.

\section{Sonuç Yerine}

Özbekistan'ın da dâhil olduğu Orta Asya coğrafyası, SSCB döneminin radikal ve ideolojik din karşıtı politikaları nedeniyle, dinin toplumsal yaşamdaki yeri konusunda oldukça sorunlu bir bölge haline dönüştürülmüştür. Ateizmin resmi devlet politikası olarak kabul edildiği geçmiş dönemlerde, dinin toplumsal hayatın her alanının dışına itilmesi sonucunda, bölgenin geleneksel dini kimlik öğelerinin temellenmiş olduğu Hanefi-Sünni İslam öğretisi bu çerçevede tabii ortamında ortaya çıkan ve şekillenen mahallî akımlar - Sufi İslam, Nakşibendîlik, Kadirilik vb. İslami cereyanlar - toplumsal dinamizmini ve rolünü önemli ölçüde yitirmiştir.

Sovyet sonrası dönemde, bağımsız Özbekistan devletinin ortaya çıkmasıyla beraber, bu yapay durum sadece tarihsel-akademik bakımdan önem arz etmekle kalmamış, özellikle toplumsal pratikte ciddi sorunları beraberinde getirmiştir. Her şeyden önce demokratikleşme ve sistem dönüşümünün istenen ölçülerde başarılı olamamasıyla beraber, siyasi muhalefet kanallarında Özbekistan'da mevcut rejimin otoriter karakteri ile ilintili problemler ortaya çıkmıştır. Tek adam yönetimi ve baskıcı-otoriter rejim, İslam konusunda çoğulcu gelişimden yana değil, devlet yönlendirmeli, kimlik inşa süreçlerinde aletselleştirilen bir tür “devlet İslamı'nı” kullanmak istemiş, bunun dışında kalan İslami akımları ise yasal zeminin dışına çekerek radikal militan grupların varoluşlarını endirekt biçimde meşrulaştırmıştır.

Ülke genelinde uygulanan baskıcı rejime rağmen, ülkenin kırsal bölgelerinde, başta Fergana bölgesi olmak üzere, devlet gücünün sürekli olarak uygulanamadığı güç boşluklarından istifade eden ve dış etkilere açık İslami gruplar ortaya çıkmış ve kısmen kitlesel destek bulmuştur. Özellikle Tacikistan ve 
Afganistan gibi yakın veya komşu bölgelerdeki İslami radikal akımların da etki alanına açık olan bu coğrafyada, özellikle bölge dışı ve aslında Orta Asya yerel İslami dokusuna da tekabül etmeyen Selefi akımlar, kendilerine giderek daha fazla yer bulmaya başlamışlardır. Özellikle 11 Eylül eylemleri ve peşi sıra bölgede hissedilen ABD ve NATO operasyonları, Özbekistan'da da radikal akımların yelkenlerine rüzgâr olmuştur. Suudi Arabistan kökenli Selefi akımların arkalarındaki finansal destekle beraber Özbekistan'ın da içinde bulunduğu siyasi koşulları kullanan bu İslamcı akımlar, her ne kadar farklı yaklaşımlar ve stratejiler de sergileseler, ortak payda olarak Özbekistan'da meşru muhalefet kanallarının kapalı olması durumundan yararlanmakta ve bölgede kendi ideolojilerini yaygınlaştırmayı hedeflemektedirler.

ÖİH ve HT akımları, bölgede demokrasi ve piyasa ekonomisi gelişimi ve buna paralel olarak da Özbekistan'in dünya toplumuna entegrasyonu ile normalleşen ve demokratikleşen bir Özbekistan'da marjinal hale getirilebilirler. Ancak gerek bölgede ve özelde Özbekistan'da yakın gelecekte bu tür bir sistemsel dönüşümün mümkün görünmemesi, gerekse de küresel düzeyde özellikle Ortadoğu'da Irak ve Suriye'de ortaya çıkan yeni İslami radikalizm IŞīD (ID), görünür bir gelecekte Orta Asya' da demokratikleşme yönünde siyasi reformların hem iç, hem de diş dinamiklerce desteklenmeyeceği doğrultusunda yorumlanabilir. Uzun vadede küresel manada hareket edebilme potansiyeline sahip bu tür radikal militan İslamcı hareketler, Orta Asya genelinde ve Özbekistan özelinde de kendilerine yayılma alanı bulabilirler. Bu tür bir durumda gerek küresel güçlerin, gerekse de başta Rusya olmak üzere bölgesel aktörlerin etkilerinin ve güç projeksiyonlarının Orta Asya'da hissedilmesi kaçınılmaz olacaktır. Özbekistan vakası, Orta Asya'yı daha iyi anlamak konusunda iyi bir başlangıç noktası teşkil etmektedir. 


\section{KAYNAKÇA}

BARAN Z. (2004), Usbekistan: The Key to Success in Cenrtal Asia, House Comitee on International Relations Subcommittee on Middle East and Central Asia, 15.

BARAN,Z,Starr,F,\& Cornell,S.E. (2006) Islamic Radicalism in Central Asia and the Caucasus: Implications for the EU, Central Asia-Caucasus Institute \& Silk Road Studies Program.

CORNELL S.E.(2005), Narcotics, Radicalism, and Armed Conflict in Central Asia: The Islamic Movement of Usbekistan, Terrorism and Political Violence, 17/619, 2005, s. 619-639.

GAZİEV,J., (2000), Islamic Revival in Post-Independence Usbekistan, The Fletcher Journal of Development Studies, Volume 16, 2000, s. 1-15.

GUNN,T.J.(2003), Shaping an Islamic Identity: Religion, Islamism, and the State in Central Asia, Sociology of Religion, 64/3, s. 389-410.

HALBACH,U, (2002) "Islam undIslamische Bewegungen in Zentralasien", Aus Politik undZeitgeschichte, B 3-4, http://www.bpb.de/apuz/27159/islam-und-islamistische-bewegungenin-zentralasien?p=all.

HANKS,R.R. (2007), "Dynamics of Islam, Identity, and Institutional Rule in Uzbekistan: Constructing a Paradigm for Conflict Resolution", Communistand Post-CommunistStudies, 40,s. 209-221.

HAYITT B, (1962) Soviet Russische Orientpolitik am Beispiel Turkestans, Köln, Berlin.

http://www.theguardian.com/world/2001/nov/26/afghanistan.iantraynor.

KARAGIANNIS,E. (2006), Political Islam in Usbekistan: Hizb-ut Tahrir al-Islami, EuropeAsia Studies, Vol. 58, No. 2, s. 261-280.

LİSNYANSKİ,D.(2008), Jihad Strategies in Central Asia, The Eight Herzliya Conference on the Balance of Israel's National Security "Israel at Sixty: Tests of Endurance", The Interdisciplinary Center Herzliya Lauder School of Government, Diplomacy and Strategy, Ocak 20-23.

MACLOAD, C.\&Mayhew,B, (1997), Usbekistan: The Golden Road to Samarkand, Passport Books.

MANN,P. (2002), Islamic Movement of Uzbekistan: Will it Strake Back?, Strategic Analysis, Vol. 26, No. 2, Nisan - Haziran, 2002, s. 294 - 304.

MARX, K,\&Kritik, Z. (1972), İçinde HegelschenRechtsphilosophie, Karl Marx \& Friedrich Engels, AusgewaehlteWerke (Der.), Cilt 1, Berlin.

McGLINCHEY,E.M, (2006) "IslamicLeaders in Usbekistan”, 1, AsiaPolicy.

NESEMANN F., (2001), Islam 1917-1941. İçinde C.Gassenschmidt\&R.Tuchtenhagen (Ed.), Politic and Religion in Soviet Union 1917-1941, Wiesbaden: HarrassowitzVerlag.

OLIMOVA, S,\&Tolipov,F (2011) "IslamicRevival in Central Asia. The Cases Uzbekistan and Tajikistan", Documentos CIDOB Asia, 26, s. 1-15.

ÖZBEKİSTAN ANAYASASI, Madde 18.

PELKMANS,M. (2006), "Religion und Kultur in Zentralasien: Sowjetische Vermächtnisse und neue Herausforderungen",Max-Planck-Gesellschaft, Tätigkeitsbericht, http://www.mpg. de/436801/pdf.pdf. 
22 • YALOVA SOSYAL BİLIMLER DERGİSI

REINER Freitag R,-Wirminghaus,(2005) "Russland, islamische Republikendes Kaukasusund Zentralasiens", W.Ende \&U. Steinbach, Der Islam in der Gegenwart, München: CH Beck s. 681-695.

SARTORİ, P, (2010) "Towards a History of theMuslims' SovietUnion: A Viewfrom Central Asia”, DieWeltdesIslams, 50, s. 317-318.

SEIFERT,A.C.(2012), Der Politische Islam in Zentralasien - Gegnero der demokratischer Partner?, Hamburg: CORE WorkingPaper, Say1 25.

TATARİ E\&Shaykhutdinov, R.,(2010), "State Response to Religious Revivalism in PostSoviet Central Asia", EuropeanJournal of EconomicandPoliticalStudies, 2, s. 85-110. 